\title{
Penerapan Metode Analytical Hierarchy Process (AHP) Pada Desain Sistem Pendukung Keputusan Pemilihan Calon Penerima Bantuan Pangan Non Tunai (BPNT) Di Kota Palangka Raya
}

Jadiaman Parhusip ${ }^{\text {a. } \text { * }^{*}}$

a. Jurusan Teknik Informatika, Kampus UPR Tunjung Nyaho Jl. Yos Sudarso Palangka Raya

1. parhusip.jadiaman@it.upr.ac.id

* corresponding author

\section{ARTICLE INFO}

\section{Keywords}

Sistem Pendukung Keputusan

Analytical Hierarchy Process

Bantuan Pangan Non Tunai

Kota Palangka Raya

Kriteria Kemiskinan

\section{ABSTRACT}

Village/ward party in Palangka Raya is required to collect data of poor people who reserve the right to receive Non-Cash Food Aid (BPNT). Eventually, village/ward party is going to work together with the census officers of Social Protection Program of Central Statistics Body (BPS) in Palangka Raya. The decision process of the recipient candidates of BPNT in Palangka Raya requires a Decision Support System which offers consideration and evaluation to obtain more accurate data. The selection uses ten poor criteria of non-monetary variable include main income, possession status of a house to live, floor material of the house, wall material of the house, facility of drinking water, facility of lighting, fuel for cooking need, facility of defecation, final disposal of feces, and asset possession of household. The research used the Decision Support System with Analytical Hierarchy Process (AHP) method. The system was evaluated by two different methods which were black box testing and turing testing. The application assists to decide the alternative recipient of BPNT, manage data of candidates of recipient of BPNT and manage data of the recipient of BPNT which were selected from the recommendation result.

\section{Pendahuluan}

\subsection{Latar Belakang}

Dalam Undang-Undang Dasar 1945 pasal 34 tertulis: "fakir miskin dan anak-anak terlantar dipelihara oleh negara; negara mengembangkan sistim jaminan sosial bagi seluruh rakyat dan memberdayakan masyarakat yang lemah dan tidak mampu sesuai dengan martabat kemanusiaan; negara bertanggung jawab atas penyediaan fasilitas kesehatan dan pelayanan umum yang layak". Pemerintah menyadari tidaklah mudah mewujudkan kesejahteraaan bagi seluruh penduduk. Mewujudkan pemenuhan hak-hak dasar warga secara layak memerlukan langkah-langkah penanganan dan pendekatan yang sistematik dan menyeluruh. Peningkatan kesejahteraan masyarakat menjadi prioritas dalam Rencana Pembangunan Jangka Menengah yang meliputi 5 (lima) sasaran pokok yaitu: pengurangan kemiskinan dan pengangguran, pengurangan kesenjangan antar wilayah, peningkatan kualitas manusia, perbaikan mutu lingkungan hidup, dan pengelolaan sumber daya alam, serta peningkatan infrastruktur. Dalam implementasinya, prioritas utama pembangunan nasional diberikan kepada pemeliharaan kesejahteraan masyarakat, penataan kelembagaan dan pelaksanaan sistem perlindungan sosial. Sasaran yang hendak dicapai melalui prioritas ini antara lain adalah peningkatan kesejahteraan masyarakat, khususnya masyarakat miskin, sehingga angka kemiskinan dapat menurun [1]

Wilayah Kota Palangka Raya juga mendapat perhatian dari pemerintah untuk memperoleh Bantuan Pangan Non Tunai (BPNT), sebelumnya dikenal dengan program beras untuk keluarga miskin (raskin) di distribusikan oleh Perum Bulog ke kantor desa/kelurahan, disebut titik distribusi. 
Program ini sebagai upaya pemerintah dalam memenuhi hak dasar masyarakat miskin terhadap kebutuhan pangan. Program ini juga merupakan wujud nyata komitmen pemerintah dalam mengurangi beban pengeluaran rumah tangga miskin. Keberhasilan Program diukur berdasarkan tingkat pencapaian indikator Enam Tepat (6 T); yaitu Tepat Sasaran, Tepat Jumlah, Tepat Harga, Tepat Waktu, Tepat Administrasi, dan Tepat Kualitas. Sejalan dengan perkembangan dalam pelaksanaan Program Raskin, sebagai upaya untuk mencapai 6 (enam) tepat, maka berbagai kebijakan akan terus dikembangkan [1]

Hambatan dalam melaksanakan dan mengkoordinasikan program baik di tingkat pemerintah pusat, pemerintah daerah maupun dengan pemangku kepentingan adalah keterbatasan data dan informasi yang terpadu terkait penduduk menengah ke bawah. Oleh sebab itu pihak desa/kelurahan wajib mendata masyarakat miskin yang berhak mendapatkan bantuan beras yang nantinya akan bekerjasama dengan petugas pendataan program perlindungan sosial pada kantor Badan Pusat Statistik serta pihak Bulog sebagai distributor beras. Kriteria untuk proses pemilihan kelayakan penerima raskin menggunakan "Kriteria kemiskinan variabel non-monetary", sebagai berikut [1]

1. Penghasilan utama;

2. Status penguasaan bangunan tempat tinggal yang ditempati;

3. Jenis lantai terluas tempat tinggal;

4. Jenis dinding terluas tempat tinggal dan kondisi dinding;

5. Fasilitas sumber air minum;

6. Fasilitas penerangan utama;

7. Bahan bakar/energi utama untuk memasak;

8. Penggunaan fasilitas tempat buang air besar;

9. Tempat pembuangan akhir tinja;

10. Kepemilikan aset rumah tangga.

\subsection{Tinjauan Literatur}

\section{Pengertian Analitycal Hierarchy Process (AHP)}

Analitycal Hierarchy Process (AHP) Adalah metode untuk memecahkan suatu situasi yang komplek tidak terstruktur kedalam beberapa komponen dalam susunan yang hirarki, dengan memberi nilai subjektif tentang pentingnya setiap variabel secara relatif, dan menetapkan variabel mana yang memiliki prioritas paling tinggi guna mempengaruhi hasil pada situasi tersebut.

Proses pengambilan keputusan pada dasarnya adalah memilih suatu alternatif yang terbaik. Seperti melakukan penstrukturan persoalan, penentuan alternatif-alternatif, penenetapan nilai kemungkinan untuk variabel aleatori, penetap nilai, persyaratan preferensi terhadap waktu, dan spesifikasi atas resiko. Betapapun melebarnya alternatif yang dapat ditetapkan maupun terperincinya penjajagan nilai kemungkinan, keterbatasan yang tetap melingkupi adalah dasar pembandingan berbentuk suatu kriteria yang tunggal.

Peralatan utama Analitycal Hierarchy Process (AHP) adalah memiliki sebuah hirarki fungsional dengan input utamanya persepsi manusia. Dengan hirarki, suatu masalah kompleks dan tidak terstruktur dipecahkan ke dalam kelomok-kelompoknya dan diatur menjadi suatu bentuk hirarki.

\section{Kelebihan Analitycal Hierarchy Process (AHP)}

Kelebihan AHP dibandingkan dengan lainnya adalah :

1. Struktur yang berhirarki, sebagai konsekwensi dari kriteria yang dipilih, sampai pada subkriteria yang paling dalam

2. Memperhitungkan validitas sampai dengan batas toleransi inkosistensi berbagai kriteria dan alternatif yang dipilih oleh para pengambil keputusan 
3. Memperhitungkan daya tahan atau ketahanan output analisis sensitivitas pengambilan keputusan.

Selain itu, AHP mempunyai kemampuan untuk memecahkan masalah yang multi obyektif dan multi-kriteria yang berdasarkan pada perbandingan preferensi dari setiap elemen dalam hirarki. Jadi, model ini merupakan suatu model pengambilan keputusan yang komprehensif [2]

Sistem Pendukung Keputusan (Inggris: decision support systems disingkat DSS) adalah bagian dari sistem informasi berbasis komputer (termasuk sistem berbasis pengetahuan (manajemen pengetahuan)) yang dipakai untuk mendukung pengambilan keputusan dalam suatu organisasi atau perusahaan. Dapat juga dikatakan sebagai sistem komputer yang mengolah data menjadi informasi untuk mengambil keputusan dari masalah semi-terstruktur yang spesifik. Menurut Moore and Chang [3] SPK dapat digambarkan sebagai sistem yang berkemampuan mendukung analisis ad hoc data, dan pemodelan keputusan, berorientasi keputusan, orientasi perencanaan masa depan, dan digunakan pada saat-saat tidak biasa.

\section{Tahapan SPK:}

- Definisi masalah

- Pengumpulan data atau elemen informasi yang relevan

- pengolahan data menjadi informasi baik dalam bentuk laporan grafik maupun tulisan

- menentukan alternatif-alternatif solusi (bisa dalam persentase)

Tujuan dari SPK:

- Membantu menyelesaikan masalah semi-terstruktur

- Mendukung manajer dalam mengambil keputusan suatu masalah

- Meningkatkan efektivitas bukan efisiensi pengambilan keputusan

Dalam pemrosesannya, SPK dapat menggunakan bantuan dari sistem lain seperti Artificial Intelligence, Expert Systems, Fuzzy Logic, dll. [3]. SPK Sistem Pendukung Keputusan (SPK) atau Decision Support System (DSS) adalah sebuah sistem yang mampu memberikan kemampuan pemecahan masalah maupun kemampuan pengkomunikasian untuk masalah dengan kondisi semi terstruktur dan tak terstruktur. Sistem ini digunakan untuk membantu pengambilan keputusan dalam situasi semi terstruktur dan situasi yang tidak terstruktur, dimana tak seorangpun tahu secara pasti bagaimana keputusan seharusnya dibuat [4] SPK bertujuan untuk menyediakan informasi, membimbing, memberikan prediksi serta mengarahkan kepada pengguna informasi agar dapat melakukan pengambilan keputusan dengan lebih baik [5].

Keluarga Miskin. Secara harfiah, kemiskinan berasal dari kata dasar miskin yang artinya tidak berharta-benda [6]. Dalam pengertian yang lebih luas, kemiskinan dapat dikonotasikan sebagai suatu kondisi ketidakmampuan baik secara individu, keluarga, maupun kelompok sehingga kondisi ini rentan terhadap timbulnya permasalahan sosial yang lain. Kemiskinan dipandang sebagai kondisi seseorang atau sekelompok orang, laki-laki dan perempuan yang tidak terpenuhi hak-hak dasarnya secara layak untuk menempuh dan mengembangkan kehidupan yang bermartabat. Dengan demikian, kemiskinan tidak lagi dipahami hanya sebatas ketidak mampuan ekonomi, tetapi juga kegagalan pemenuhan hak-hak dasar dan perbedaan perlakuan bagi seseorang atau sekelompok orang, dalam menjalani kehidupan secara bermartabat. Hidup miskin bukan hanya berarti hidup di dalam kondisi kekurangan sandang pangan, dan papan. Akan tetapi, kemiskinan juga berarti akses yang rendah dalam sumber daya dan aset produktif untuk memperoleh kebutuhan-kebutuhan hidup, antara lain: ilmu pengetahuan, informasi, teknologi, dan modal [7]

\subsection{Alasan Penelitian Diadakan}




\section{JURNAL TEKNOLOGI INFORMASI}

[E-ISSN 2656-0321]

[Vol 13. No. 2]

Jurnal Keeilmutan dan Aplikasi Bidang Teknik Informailka

[Agustus 2019]

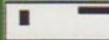

Proses analisis sangat diperlukan untuk mendapatkan ketepatan penentuan keluarga yang lebih tepat untuk menerima program raskin atau disebut juga keluarga penerima manfaat (KPM), penelitian ini menggunakan metode Analytical Hierarchy Process (AHP).

\subsection{Pertanyaan Tujuan}

Aplikasi ini membantu dalam menentukan alternatif penerima raskin atau keluarga penerima manfaat, membantu pengelolaan data calon penerima dan pengelolaan data penerima yang dipilih dari hasil rekomendasi.

\section{Metodologi Penelitian}

Data diperoleh oleh beberapa kelompok pengumpul data sebagaimana terdapat pada gambar 1. Data olahan didapatkan dari kuesioner dengan menggunakan metode pendekatan Analytical Hierarchi Process (AHP) untuk kemudian direkam dan diuji dengan menggunakan program komputer yang dibuat khusus untuk keperluan penelitian ini menggunakan bahasa pemrograman PHP dan menggunakan basisdata MySQL.

\section{Pengumpulan Data}

Untuk mengumpulkan data dan informasi yang diperlukan, dilakukan dengan pengumpulan data primer yakni dengan mendatangi tempat tinggal dan melakukan pemeriksaan pada keluarga yang sebelumnya telah ditentukan menjadi sasaran. Dalam penelitian ini penggunaan istilah keluarga calon penerima beras miskin dan keluarga penerima manfaat digunakan secara bergantian untuk maksud yang sama.

\section{Instrumen Penelitian}

Penelitian ini menggunakan angket atau kuesioner yang berfungsi sebagai instrumentasi guna memperoleh data dalam penentuan keluarga yang layak mendapatkan status keluarga yang pantas menjadi Keluarga Penerima Manfaat pada wilayah kota Palangka Raya. 


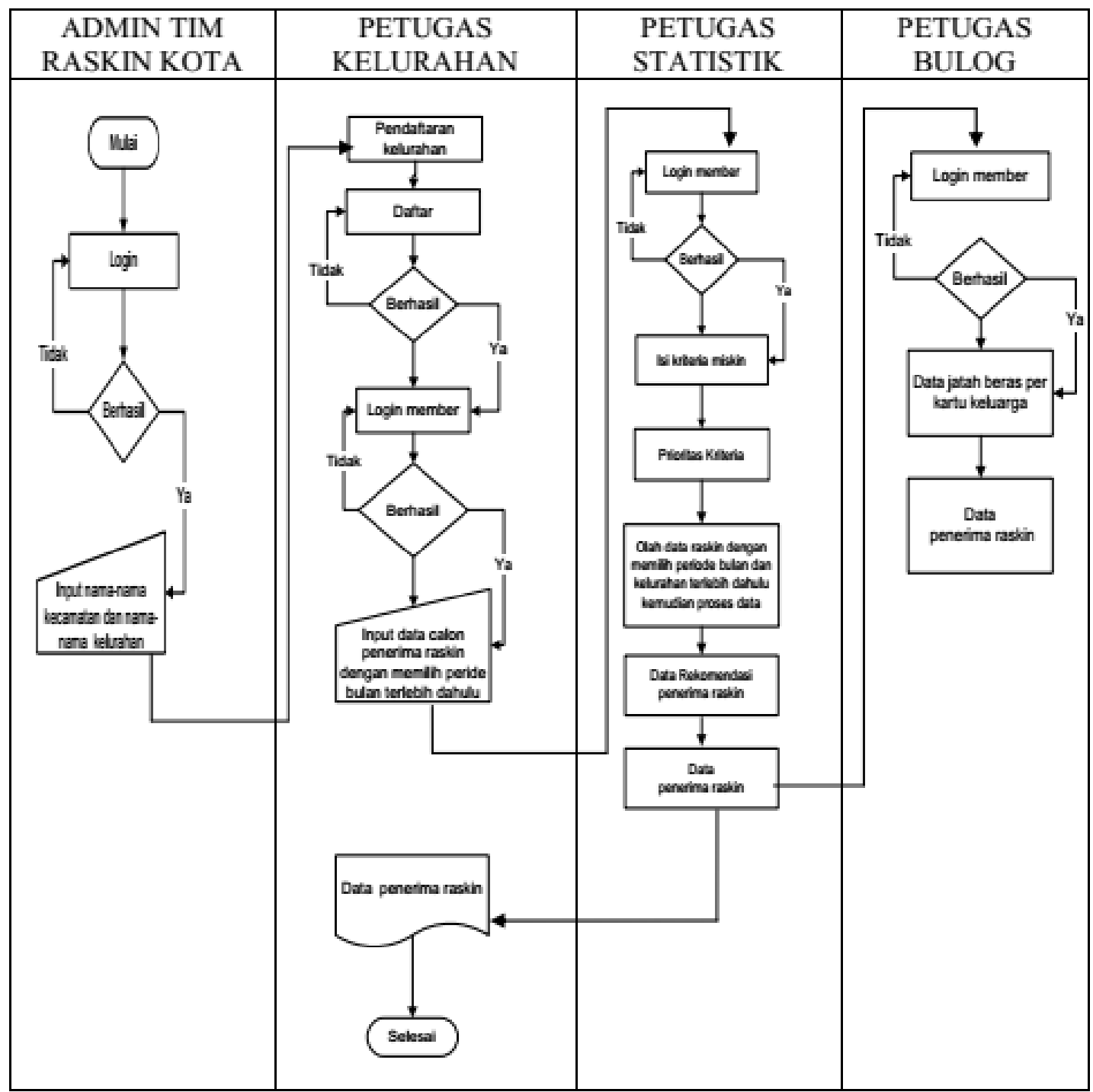

Gambar 1. Tim Pengumpulan Data Penduduk Calon Keluarga Penerima Manfaat di Kota Palangka Raya Teknik Analisis Penentuan Rekomendasi Calon Penerima Raskin

Penentuan rekomendasi calon penerima raskin dilakukan dengan menggunakan metode AHP. Flowchart dalam menentukan rekomendasi calon penerima raskin dapat dilihat pada Gambar 2 


\section{JURNAL TEKNOLOGI INFORMASI}

[E-ISSN 2656-0321]

[Vol 13. No. 2]

\section{! _ J Junal Keilmutan dan Aplikasi Bidang Teknik Iniormatika}

[Agustus 2019]

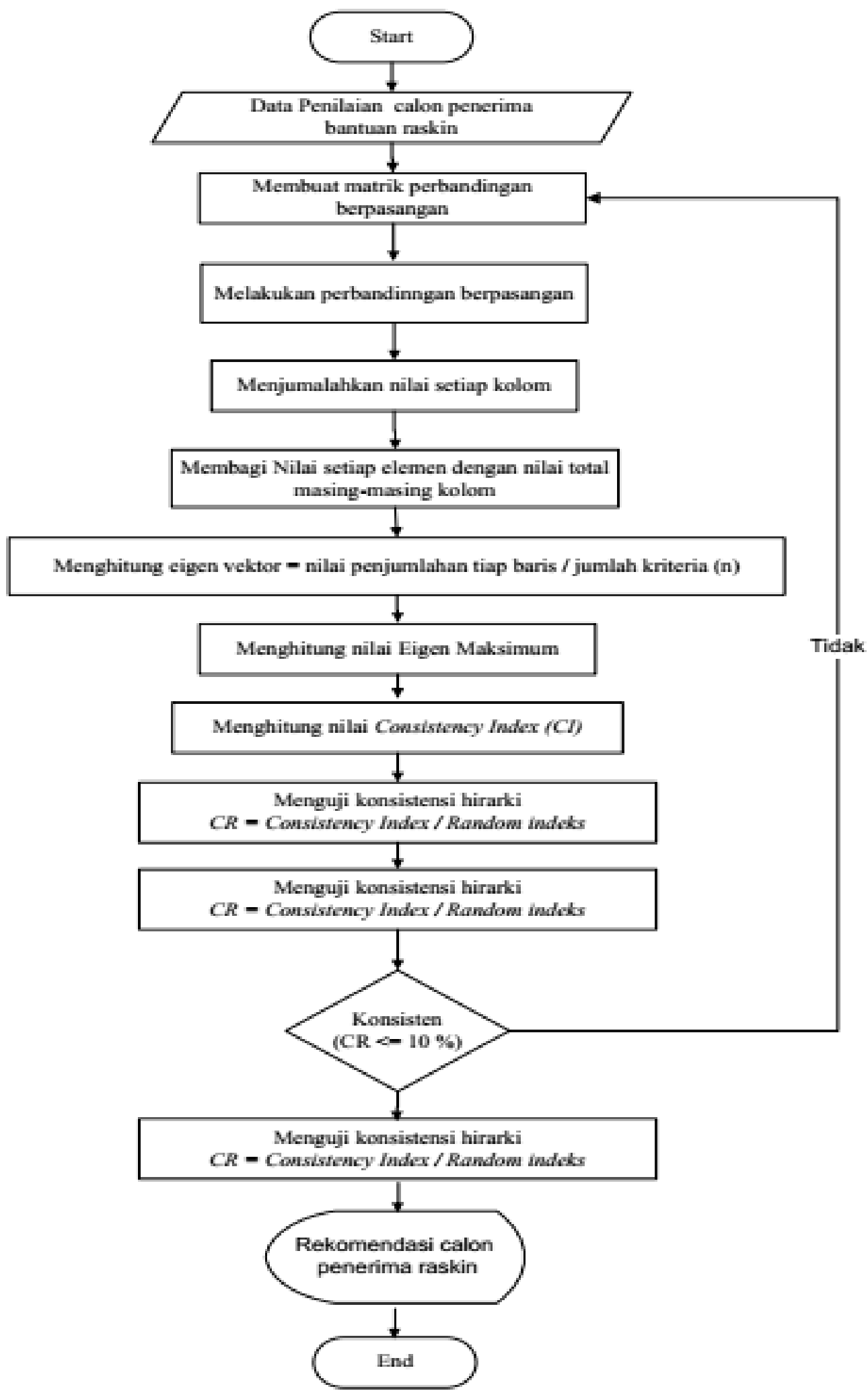

Gambar 2. Tahapan Analisis Penentuan Rekomendasi Calon Penerima BPNT 


\section{JURNAL TEKNOLOGI INFORMASI}

Jurnal Keeilmutan dann Aplikasi Bithang Teknik Informatika

[E-ISSN 2656-0321]

[Vol 13. No. 2]

[Agustus 2019]

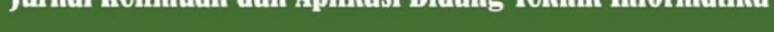

\section{Hasil dan Pembahasan}

Penentuan Keluarga Calon Penerima BPNT menggunakan sejumlah kriteria yang telah ditentukan sebelumnya.

Langkah-langkah penyelesaian perhitungan AHP

3.1 Mendefinisikan masalah dan menentukan cara pemecahan masalah yang diinginkan.

Kriteria miskin yang digunakan untuk menentukan calon penerima raskin adalah sebagai berikut :
a. Penghasilan utama
b. Bangunan tempat tinggal
c. Fasilitas Air Minum
d. Fasilitas Penerangan
e. Bahan Bakar untuk Memasak
f. Fasilitas Buang Air Besar
g. Jenis Lantai Tempat Tinggal
h. Jenis Dinding Tempat Tinggal
i. Aset Rumah Tangga Yang Paling Mahal
j. Tempat Pembungan Akhir Tinja

3.2 Membuat struktur hirarki yang diawali dengan tujuan

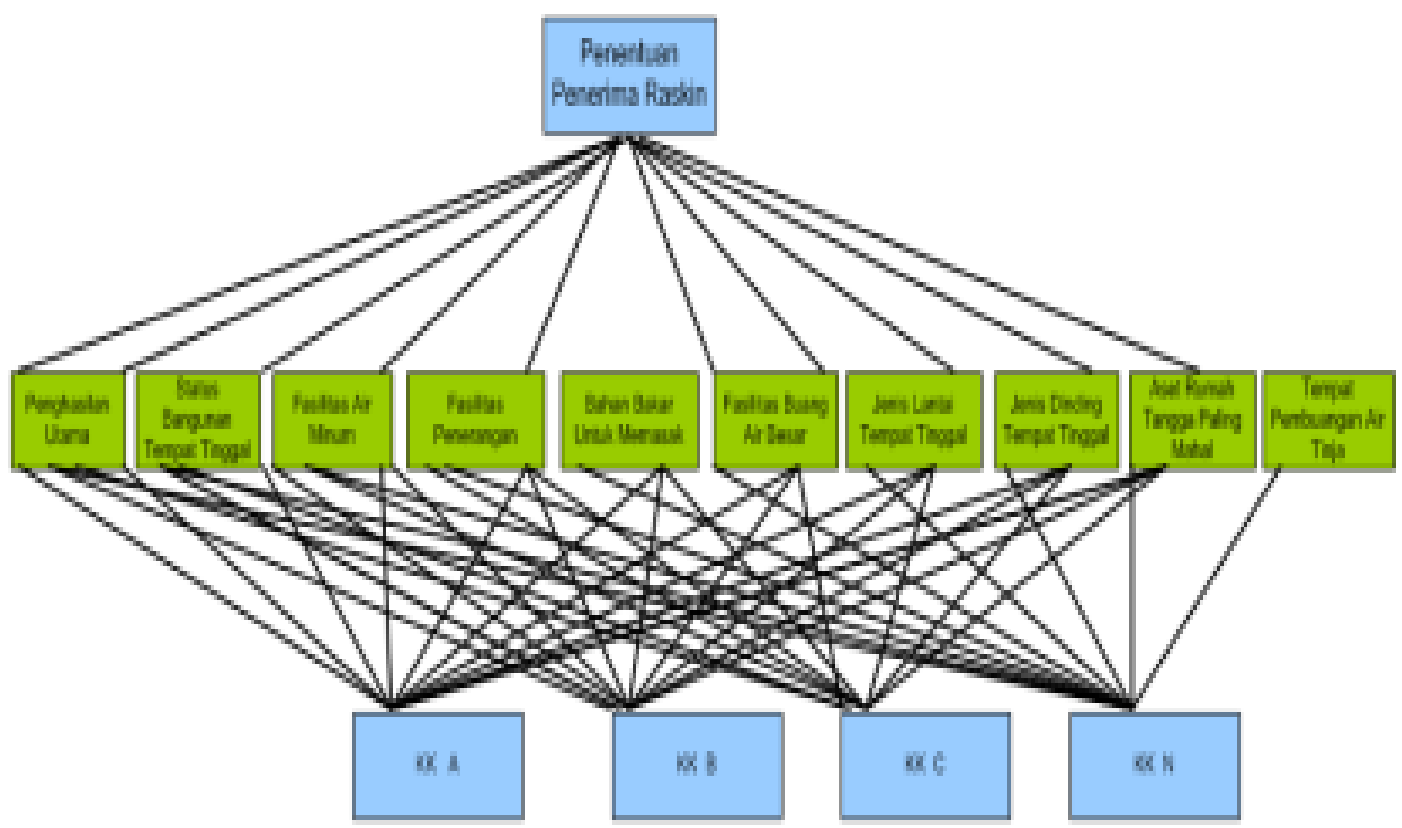

Gambar 3. Susunan Hirarki Permasalahan Yang Dihadapi

3.3 Membuat matrik perbandingan berpasangan kriteria untuk bantuan raskin Mendefinisikan perbandingan berpasangan sehingga diperoleh jumlah penilaian seluruhnya sebanyak $\mathrm{n} \times[(\mathrm{n}-1) / 2]$ buah, dengan $\mathrm{n}$ adalah banyaknya elemen yang dibandingkan. 
Tabel 1. Skala Perbandingan Berpasangan

\begin{tabular}{|c|c|c|}
\hline $\begin{array}{l}\text { Iotensitas } \\
\text { Kepentingan }\end{array}$ & Koterangan & Ponjolasan \\
\hline 1 & Kedua elemen sama pentingnya. & Dua elemen mempumyai pengaruh yang sama besat. \\
\hline 3 & $\begin{array}{l}\text { Elemen yang satu sedikit lebih } \\
\text { penting dari elemen yang lain. }\end{array}$ & $\begin{array}{l}\text { Penealaman dan penilaian sedikit menyohone satu } \\
\text { elemen dibandingkan elemen yang lainnya }\end{array}$ \\
\hline 5 & $\begin{array}{l}\text { Elemen yang satu lebih penting } \\
\text { dari eiemen yans lain. }\end{array}$ & $\begin{array}{l}\text { Pengalaman daa penilaian sangat kuat memyokang } \\
\text { satu elemen dibandingkan elemen yane lainnya. }\end{array}$ \\
\hline 7 & $\begin{array}{l}\text { Satu eiemen jelas lebih mutlak. } \\
\text { penting dari elemen lainnya. }\end{array}$ & $\begin{array}{l}\text { Satu elemen yang buat disolvane dan dominan } \\
\text { terlihat dalam praktek. }\end{array}$ \\
\hline 9 & $\begin{array}{l}\text { Satu elemen mutlak penting dari } \\
\text { elemen lainnya. }\end{array}$ & $\begin{array}{l}\text { Bukti yang mendukung elemen vang satu terhadap } \\
\text { elemen lain memiliki tingkat penegasan tertinggi } \\
\text { yang mungkin menguatkan. }\end{array}$ \\
\hline $2,4,6,8$ & $\begin{array}{l}\text { Nilai-nilai antara dua nilai } \\
\text { pertimbangan yang berdekatan }\end{array}$ & $\begin{array}{l}\text { Nilai ini diberikan bila ada dua kompromi diantara } 2 \\
\text { pilihan. }\end{array}$ \\
\hline Kebatsan & \multicolumn{2}{|c|}{$\begin{array}{l}\text { Jika altivitas i mendapat } 1 \text { angka dibandingkan dengan altivitas i, maka j memiliki nilai } \\
\text { kebalikannya dibandingkan dengan nilai } i .(1 / 2,1 / 3,1 / 4,1 / 5,1 / 6,1 / 7,1 / 8,1 / 9)\end{array}$} \\
\hline
\end{tabular}

Tabel 2. Matrik Perbandingan Kriteria

\begin{tabular}{|c|c|c|c|c|c|c|c|c|c|c|}
\hline Kateris & $\begin{array}{c}\text { Penfuastan } \\
\text { Uams }\end{array}$ & \begin{tabular}{|c|} 
Stsus \\
benpunas \\
tensattrogal
\end{tabular} & $\begin{array}{c}\text { fasilus ar } \\
\text { minum }\end{array}$ & $\begin{array}{c}\text { Fasitas } \\
\text { Penerogen }\end{array}$ & $\begin{array}{c}\text { Bynan takat } \\
\text { unk } \\
\text { menasak }\end{array}$ & $\begin{array}{l}\text { Fasiltss } \\
\text { buervat } \\
\text { Dess }\end{array}$ & $\begin{array}{l}\text { Jetie Lantis } \\
\text { Tarest } \\
\text { Thoses }\end{array}$ & \begin{tabular}{|c|} 
Jenis Dinding \\
Terost \\
Tross
\end{tabular} & $\begin{array}{l}\text { Aet Rurnat } \\
\text { Tatoge Yare } \\
\text { Paing Uatal }\end{array}$ & $\begin{array}{c}\text { Temtal } \\
\text { Pentousngas } \\
\text { Mari Thia }\end{array}$ \\
\hline $\begin{array}{l}\text { Penghasinn } \\
\text { Ctams }\end{array}$ & 1 & $3 \quad$ & $5 \quad$ & 5 & $1 *$ & $7 \quad$ & $1 *$ & $\tau$ & $T$ & * \\
\hline $\begin{array}{l}\text { Pats tanguran } \\
\text { porpat thy;al }\end{array}$ & 0.33: & 1 & $3 \times$ & 3 & $13 \cdot$ & 5 & $113 *$ & 5 & v & . \\
\hline $\begin{array}{l}\begin{array}{l}\text { Fsiltas air } \\
\text { ninum }\end{array} \\
\end{array}$ & 02 & 0.338 & 1 & $1 \quad$ & 15 . & $3 \quad *$ & $16 *$ & 3 & 3 & . \\
\hline $\begin{array}{l}\text { Fatitas } \\
\text { Pentangat }\end{array}$ & 02 & 0.332 & 1 & 1 & $15 *$ & $3 \quad$ & $16 *$ & 3 & * & . \\
\hline $\begin{array}{l}\text { Balan balar urtak } \\
\text { memasak. }\end{array}$ & 1 & 3 & 5 & 5 & 1 & $7 \quad$ & $1 *$ & $T$ & $T$ & * \\
\hline $\begin{array}{l}\text { Fasiltas buemair } \\
\text { posas }\end{array}$ & 0.16 & 0.2 & 0.300 & $0.3 x$ & 0.46 & 1 & $1 \pi \cdot$ & 1 & 1 & $13 *$ \\
\hline \begin{tabular}{|l|} 
Jetis Lansi \\
Tenoat Thassal
\end{tabular} & 1 & 3 & 5 & 5 & 1 & 7 & 1 & $7 \quad$ & 7 & * \\
\hline \begin{tabular}{|l|} 
Jene Dinting \\
Tengx: Tias:al
\end{tabular} & D.1E & 0.2 & 0.339 & 0.338 & 0.148 & 1 & D1E & 1 & $1 *$ & $13 \cdot$ \\
\hline $\begin{array}{l}\text { loot Rumah } \\
\text { Tansga Yarg } \\
\text { Paling Uatal }\end{array}$ & D.te & 0.2 & 0.338 & 0.338 & 0.48 & 1 & 0.12 & 1 & 1 & $13 *$ \\
\hline $\begin{array}{l}\text { Terosat } \\
\text { Pynbuanan watr } \\
\text { Thya }\end{array}$ & 02 & 0.338 & 1 & 1 & 02 & 3 & 12 & 3 & 3 & 1 \\
\hline
\end{tabular}

3.4 Menghitung nilai eigen dan menguji konsistensinya

Tabel 3. Matrik Penjumlahan Kolom Kriteria Miskin 
[E-ISSN 2656-0321]

[Vol 13. No. 2]

JURNAL TEKNOLOGI INFORMASI

[Agustus 2019]

Jurnal Keilmutan dan Aplikasi Bidang Teknik Informatika

Watrks fertondegan Berpasangas, Total fer Kolom

\begin{tabular}{|c|c|c|c|c|c|c|c|c|c|c|}
\hline Nitlaria & $\begin{array}{l}\text { Penchaslen } \\
\text { Utana }\end{array}$ & $\begin{array}{c}\text { Stetss } \\
\text { basguran } \\
\text { terpat tongyal }\end{array}$ & $\begin{array}{l}\text { Fasditas } \\
\text { arminum }\end{array}$ & $\begin{array}{l}\text { Fasiltas } \\
\text { Penerengan }\end{array}$ & $\begin{array}{c}\text { Eahen bacar } \\
\text { untsk } \\
\text { mameask }\end{array}$ & $\begin{array}{l}\text { Faslias } \\
\text { buengair } \\
\text { besar }\end{array}$ & $\begin{array}{c}\text { Jeris Lartal } \\
\text { Tanos: } \\
\text { Tinggal }\end{array}$ & \begin{tabular}{|c|} 
Teris Dinding \\
Taroz: \\
Tinggal
\end{tabular} & $\begin{array}{l}\text { Acet Rumah } \\
\text { Tangga Fang } \\
\text { Palng Uatal }\end{array}$ & $\begin{array}{c}\text { Taroa: } \\
\text { Panbuangan } \\
\text { Notie Tria }\end{array}$ \\
\hline Pangasian Utamo & 1 & 3 & 5 & 5 & 1 & 7 & 1 & 7 & 7 & 5 \\
\hline $\begin{array}{l}\text { Gatus tangiran } \\
\text { lempot ing:al }\end{array}$ & 0.333 & 1 & 3 & 3 & 1333 & 5 & 0.333 & 5 & 5 & 3 \\
\hline Fagltas air minun & 02 & 0.333 & 1 & 1 & 12 & 3 & 0.2 & 3 & 3 & 1 \\
\hline $\begin{array}{l}\text { Fasitas } \\
\text { Penatangas }\end{array}$ & 0.2 & 0.333 & 1 & 1 & 12 & 3 & 0.2 & 3 & 3 & 1 \\
\hline $\begin{array}{l}\text { Bahas bokar urtuk } \\
\text { menasak. }\end{array}$ & 1 & 3 & 5 & 5 & 1 & $T$ & 1 & 7 & 7 & 5 \\
\hline $\begin{array}{l}\text { Fesiltas buangair } \\
\text { besar }\end{array}$ & 0.143 & 0.2 & 0.333 & 1.353 & 0.143 & 1 & 0.143 & 1 & 1 & 0.333 \\
\hline 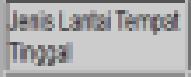 & 1 & 3 & 6 & 5 & 1 & 7 & 1 & 7 & 7 & 6 \\
\hline $\begin{array}{l}\text { Jere Dinting } \\
\text { Tenex: Tin:5al }\end{array}$ & 0.143 & 0.2 & 0333 & 0.333 & 2.143 & 1 & 0.143 & 1 & 1 & 0333 \\
\hline $\begin{array}{l}\text { Kest Rarnat Tang5a } \\
\text { Yavg Paing Uatal }\end{array}$ & Q 143 & 0.2 & 0.333 & 1333 & 0.143 & 1 & Q.43 & 1 & 1 & 0.333 \\
\hline $\begin{array}{l}\text { Tenex: } \\
\text { Pensuzngan Atir } \\
\text { Thia }\end{array}$ & 02 & 0.333 & 1 & 1 & 12 & 3 & 02 & 3 & 3 & 1 \\
\hline Thed & 4362 & 11569 & 21569 & 21.999 & 4362 & 33 & 4.32 & 30 & 38 & 21.549 \\
\hline
\end{tabular}

Tabel 4. Matrik Pembagian Setiap Elemen Kriteria Miskin dan Prioritas Kriteria Miskin

\begin{tabular}{|c|c|c|c|c|c|c|c|c|c|c|c|c|}
\hline Krteria & $\begin{array}{c}\text { Pangtasian } \\
\text { Uarua }\end{array}$ & $\begin{array}{c}\text { Guses } \\
\text { bavguran } \\
\text { xmpat thoga }\end{array}$ & $\begin{array}{l}\text { Facil tas } \\
\text { Girminun }\end{array}$ & $\begin{array}{c}\text { Faslitac } \\
\text { Punerangan }\end{array}$ & $\begin{array}{c}\text { Batan bacar } \\
\text { Irtuk } \\
\text { memasak }\end{array}$ & $\begin{array}{c}\text { fastlas } \\
\text { buangar } \\
\text { tesar }\end{array}$ & $\begin{array}{l}\text { Jenes } \\
\text { Lartai } \\
\text { Temeat } \\
\text { Tisgsal }\end{array}$ & $\begin{array}{l}\text { Jenis } \\
\text { Dinding } \\
\text { Tempat } \\
\text { Tifeged }\end{array}$ & $\begin{array}{l}\text { Aest Rumat } \\
\text { Tangy Yang } \\
\text { Paling llahal }\end{array}$ & $\begin{array}{l}\text { Terntat } \\
\text { Pembusngan } \\
\text { Ahir Thia }\end{array}$ & Total & Pitcritas \\
\hline $\begin{array}{l}\text { Penghaslan } \\
\text { Itama }\end{array}$ & 0.229 & 1289 & 0.221 & 0227 & 0.229 & 0.134 & 0.229 & 2.184 & 0.184 & 0.227 & 2.179 & 0218 \\
\hline $\begin{array}{l}\text { Gatus tangunan } \\
\text { fompot tingazal }\end{array}$ & D.078 & 1.006 & 2.136 & 0.139 & 0.676 & 0.132 & 0676 & 0.12 & 0.132 & 0.126 & 1,118 & ast2 \\
\hline $\begin{array}{l}\text { Foiltas air } \\
\text { minum }\end{array}$ & 0.045 & 1000 & 0.045 & 0.045 & 0.46 & 0.975 & 0.46 & a 079 & 0.778 & 0.145 & 1.530 & 1.054 \\
\hline $\begin{array}{l}\text { Facltas } \\
\text { Penatangan }\end{array}$ & $0.0 \% 5$ & 0.009 & 0.045 & 0.045 & 0.546 & 0.073 & 0.046 & 2079 & 0.079 & 0.145 & 1509 & 0.054 \\
\hline $\begin{array}{l}\text { Batas toikar } \\
\text { Intuk memasak }\end{array}$ & 0228 & 1289 & 0.227 & 0227 & 0.228 & 0.114 & 0.229 & 2.164 & 0.114 & 0.227 & 2.179 & c213 \\
\hline $\begin{array}{l}\text { fositas busmat } \\
\text { bess }\end{array}$ & 0009 & 0.017 & 0015 & 0.015 & $0 \cos 3$ & 0.426 & o vos & 1006 & 0126 & 0.115 & 1.299 & 0.004 \\
\hline $\begin{array}{l}\text { Janis Larta } \\
\text { Thenes: Tiagsal }\end{array}$ & 0.229 & 1280 & $0.22 \pi$ & 0.227 & 0.229 & 0.114 & 0.229 & 0.184 & 0.154 & 0.227 & 2.179 & 0218 \\
\hline $\begin{array}{l}\text { Jene Dinting } \\
\text { Tungat Thaggal }\end{array}$ & 0.053 & 0.017 & 2.015 & 0.015 & 0.038 & 0.228 & 0.036 & 1.066 & 0.126 & 0.415 & 1258 & 0.024 \\
\hline $\begin{array}{l}\text { feet Rumah } \\
\text { Tangsa Yang } \\
\text { Paling Matal }\end{array}$ & 0.033 & 0.017 & 0.015 & 0.015 & 0.033 & 0.228 & 0.053 & 1.065 & 0.126 & 0.115 & 12259 & 0.024 \\
\hline $\begin{array}{l}\text { Teres } \\
\text { Pernbuangat } \\
\text { whr Thya }\end{array}$ & D.0.5 & 1009 & 0.045 & 0.045 & 0.046 & 0.193 & 0.046 & 2079 & 0.078 & 0.045 & 2589 & 0.054 \\
\hline
\end{tabular}


Menghitung nilai consistency index

$$
\begin{aligned}
\lambda \text { maks }= & 4.362(0.218)+11.599(0.112)+21.999(0.054)+21.999(0.054)+4.362 \\
& (0.218)+38(0.024)+4.362(0.218)+38(0.024)+38(0.024)+21.999 \\
& (0.054) \\
= & 0.950916+1.299088+1.187946+1.187946+0.950916+0.912+ \\
& 0.950916+0.912+0.912+1.187946 \\
= & 10.452 \\
\mathrm{CI}= & \frac{\lambda_{\text {maks }}-n}{n-1}=\frac{10.452-10}{10-1}=\frac{0.4516}{9}=0.05
\end{aligned}
$$

\section{Menghitung nilai consistency ratio}

$$
\begin{aligned}
C R=\frac{C I}{R I}=\frac{0.05}{1.49} & =0.0334 \\
& =3.4 \%
\end{aligned}
$$

3.5 Mengulangi langkah 3 dan 4 untuk seluruh tingkat hirarki.

3.6 Menghitung vektor eigen dari setiap matriks perbandingan berpasangan

Seperti proses diatas menghitung vektor eigen dari setiap matrik berpasangan yaitu meliputi ; menjumlahkan nilai setiap kolom dari matrik, membagi setiap kolom dengan total kolom yang bersangkutan, serta menjumlahkan nilai dari setiap baris dan membaginnya dengan jumlah elemen untuk mendapatkan nilai rata-rata.

\subsection{Memeriksa Konsistensi Hirarki}

Konsistensi hirarki yang harus dihitung ada 11, yaitu:

a. Konsistensi hirarki kriteria miskin

b. Konsistensi hirarki alternatif terhadap kriteria penghasilan utama

c. Konsistensi hirarki alternatif terhadap kriteria status bangunan tempat tinggal

d. Konsistensi hirarki alternatif terhadap kriteria fasilitas air minum

e. Konsistensi hirarki alternatif terhadap kriteria fasilitas penerangan

f. Konsistensi hirarki alternatif terhadap kriteria bahan bakar memasak

g. Konsistensi hirarki alternatif terhadap kriteria fasilitas buang air besar

h. Konsistensi hirarki alternatif terhadap kriteria lantai tempat tinggal

i. Konsistensi hirarki alternatif terhadap kriteria jenis dinding tempat tinggal

j. Konsistensi hirarki alternatif terhadap kriteria aset rumah tangga paling mahal

k. Konsistensi hirarki alternatif terhadap kriteria tempat pembuangan air tinja

Tabel hasil perhitungannya adalah sebagai berikut. 


\begin{tabular}{|c|c|c|c|c|c|c|}
\hline & Kriteria & $\begin{array}{l}\text { Penghasil } \\
\text { an utama }\end{array}$ & \multicolumn{2}{|c|}{$\begin{array}{l}\text { Status Bangunan } \\
\text { Tempat tinggal }\end{array}$} & $\begin{array}{c}\begin{array}{c}\text { Fasilitas air } \\
\text { minum }\end{array} \\
\end{array}$ & $\begin{array}{c}\text { Fasilitas } \\
\text { penerangan }\end{array}$ \\
\hline $\mathrm{n}$ & 10 & 3 & \multicolumn{2}{|l|}{3} & 3 & 3 \\
\hline CI & 0.05 & 0.01789 & \multicolumn{2}{|c|}{-0.00033} & \begin{tabular}{|l|l|l|}
-0.00016 \\
\end{tabular} & 0.01768 \\
\hline CR & 3.4 & 3.0850 & \multicolumn{2}{|c|}{-0.05747} & -0.02873 & \begin{tabular}{|l|l|}
3.04968 \\
\end{tabular} \\
\hline & \begin{tabular}{|l|} 
Bahan \\
bakar untuk \\
memasak
\end{tabular} & $\begin{array}{l}\text { Fasilitas } \\
\text { buang } \\
\text { air } \\
\text { besar }\end{array}$ & $\begin{array}{l}\text { Jenis } \\
\text { lantai } \\
\text { tempat } \\
\text { tinggal }\end{array}$ & \begin{tabular}{|l|} 
Jenis \\
dinding \\
tempat \\
tinggal
\end{tabular} & \begin{tabular}{|l|} 
Aset \\
rumah \\
tangga \\
paling \\
mahal \\
\end{tabular} & \begin{tabular}{|l|} 
Tempat \\
pembuangan \\
akhir tinja
\end{tabular} \\
\hline $\mathrm{n}$ & 3 & 3 & 3 & 3 & 3 & 3 \\
\hline CI & 0.021 & 0.04842 & 0.00033 & 0.01118 & 0.00033 & 0.01134 \\
\hline CR & \begin{tabular}{|l}
3.72194 \\
\end{tabular} & 8.3486 & 0.05746 & \begin{tabular}{|l|l|}
1.92874 \\
\end{tabular} & 0.05746 & 1.95626 \\
\hline
\end{tabular}

Karena nilai CR untuk setiap matrik yang telah dihitung konsistensinya bernilai $\leq 10 \%$, maka hirarki dinyatakan konsisten.

Tabel 6. Hasil Akhir (Rekomendasi)

\begin{tabular}{|c|c|c|c|c|c|c|c|c|c|c|c|}
\hline & $\begin{array}{l}\text { penghasilan } \\
\text { utama }\end{array}$ & \begin{tabular}{|c|} 
stavis \\
bangunx \\
vempen \\
tinggal
\end{tabular} & $\begin{array}{l}\text { fasilinas } \\
\text { gif } \\
\text { minum }\end{array}$ & $\begin{array}{c}\text { fasilitas } \\
\text { penerangr }\end{array}$ & $\begin{array}{c}\text { bahan } \\
\text { bakat } \\
\text { untak } \\
\text { memasak }\end{array}$ & $\begin{array}{c}\text { fasilias } \\
\text { buang aif } \\
\text { besal }\end{array}$ & $\begin{array}{c}\text { jenis lantal } \\
\text { tempat } \\
\text { tungal }\end{array}$ & $\begin{array}{l}\text { jetis finding } \\
\text { vempot } \\
\text { tinged }\end{array}$ & $\begin{array}{c}\text { ast rumah } \\
\text { tange } \\
\text { yang } \\
\text { paling } \\
\text { mahal }\end{array}$ & $\begin{array}{c}\text { Iempot } \\
\text { pembrangan } \\
\text { akhir tinja }\end{array}$ & total \\
\hline & 99 & 0.015952 & 12314 & 0.00 & 0.0343786 & 0.0067348 & 106 & 392 & 0.0026664 & 0.00 & 0.216478 \\
\hline Alte & 04531 & 0.045003 & 0.007706 & 0.021397 & 0.142899 & 0.0017712 & 0.1017188 & 0.0028824 & 0.0026664 & 0.0072405 & 0.441322 \\
\hline Alt & 0250482 & 0.043003 & .02314 & 0.025893 & 0.0405758 & 0.015416 & 0.1017188 & 0.1000461 & 0.0186648 & 0.040257 & 0.438596 \\
\hline
\end{tabular}

Hasil akhir didapatkan dengan cara mengalikan nilai prioritas kriteria dengan nilai prioritas setiap alternatif setiap alternatif terhadap kriteria dan kemudian hasil perkalian tersebut dijumlahkan untuk mengetahui totalnya.

Kesimpulan Untuk Hasil Akhir (Rekomendasi) :

Untuk kriteria alternatif atau calon penerima manfaat dapat dilihat bahwa alternatif 2 mendapatkan nilai tertinggi maka menjadi prioritas utama disusul alternatif 3 , dan alternatif 1 .

\section{Kesimpulan}

Sistem Penunjang Keputusan untuk program BPNT se-kota Palangka Raya ini dibuat sebagai sarana pengambilan keputusan penentuan masyarakat miskin yang berhak mendapatkan beras untuk rumah tangga miskin atau keluarga penerima manfaat atau BPNT di kota Palangka Raya, dimana sistem ini tidak menangani persediaan dan pendistribusian beras. Aplikasi ini membantu dalam menentukan alternatif penerima manfaat, membantu pengelolaan data calon penerima manfaat dan pengelolaan data penerima yang dipilih dari hasil rekomendasi.

Kriteria yang digunakan terdiri dari 10 kriteria, yaitu : penghasilan utama, status penguasaan bangunan tempat tinggal yang ditempati, jenis lantai tempat tinggal, jenis dinding tempat tinggal, fasilitas sumber air minum, fasilitas penerangan, bahan bakar utuk memasak, fasilitas buang air besar, tempat pembuangan akhir tinja, kepemilikan aset rumah tangga. Bahasa yang digunakan untuk 


\section{JURNAL TEKNOLOGI INFORMASI}

[E-ISSN 2656-0321]

[Vol 13. No. 2]

Jurnal Keilmutan dan Apilkasi Bidtang Teknik Informatika

[Agustus 2019]

membangun website raskin ini yaitu $P H P$, dan MySQL sebagai database. Metode pengembangan yang digunakan yaitu metode waterfall dan sistem pendukung keputusan dengan metode Analytical Hierarchy Process (AHP).

\section{Daftar Pustaka}

[1] Anonim, Pedoman Umum Penyaluran RASKIN (Beras Untuk Rumah Tangga Miskin). Jakarta: Kementerian Koordinator Bidang Kesejahteraan Rakyat, 2014.

[2] Bambang Wisanggeni. (2010, Mar.) bambangwisanggeni.wordpress.com. [Online]. https://bambangwisanggeni.wordpress.com/2010/03/02/analytical hierarchy process-ahp

[3] id.wikipedia.org. [Online]. https://id.wikipedia.org/wiki/Sistem Pendukung Keputusan

[4] Efraim Turban and Jay E. Aronson, Decision Support System and Intelligent Sistem. New Jersey, Upper Saddle River: Prentice Hall, 2001.

[5] (2013, Sep.) www.kajianpustaka.com. [Online]. https://kajianpustaka.com/2013/09/sistem pendukung keputusan-spk.html

[6] W. J. S. Poerwadarminta, Kamus Besar Baasa Indonesia. Jakarta: PN. Balai Pustaka, 1976.

[7] idtesis.com. [Online]. https://idtesis.com/pengertian-keluarga-miskin/ 